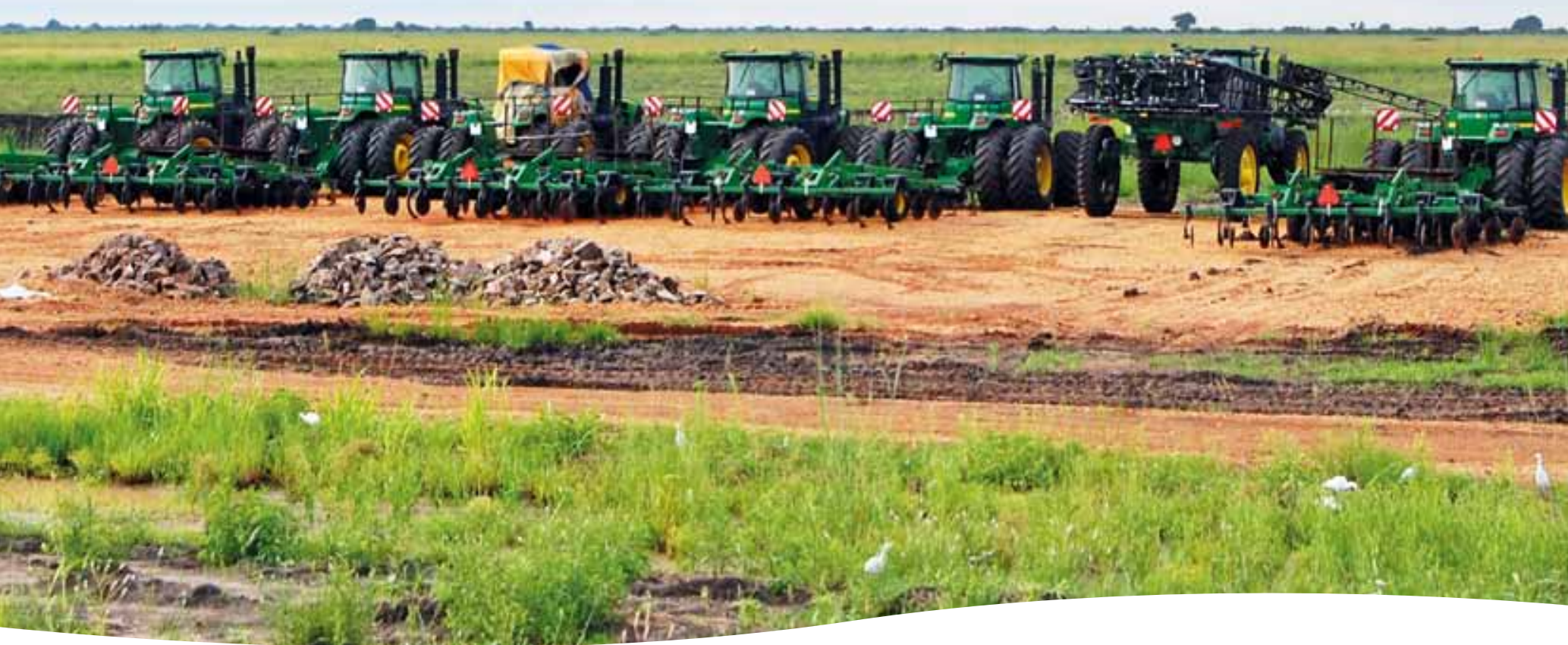

\title{
The anatomy of large-scale farmland acquisitions in sub-Saharan Africa
}

George C. Schoneveld

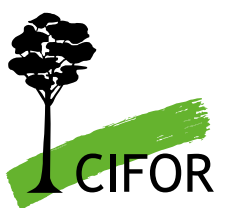





\section{The anatomy of large-scale farmland acquisitions in sub-Saharan Africa}

George C. Schoneveld 
Working Paper 85

(C) 2011 Center for International Forestry Research

All rights reserved

Schoneveld, G.C. 2011 The anatomy of large-scale farmland acquisitions in sub-Saharan Africa. Working paper 85 . CIFOR, Bogor, Indonesia.

Cover photo by George C. Schoneveld. Introduction of mechanised agriculture in Gambella, Ethiopia

This publication was produced with the financial assistance of the European Union, under the project 'Bioenergy, sustainability and trade-offs: Can we avoid deforestation while promoting bioenergy?' European Community Contribution Agreement EuropeAid/ENV/2007/143936/TPS.

The project aims to contribute to sustainable bioenergy development that benefits local people in developing countries, minimises negative impacts on local environments and rural livelihoods, and contributes to global climate change mitigation. The project will achieve this by producing and communicating policy-relevant analyses that can inform government, corporate and civil society decision making related to bioenergy development and its effects on forests and livelihoods. The project is managed by CIFOR and implemented in collaboration with the Council on Scientific and Industrial Research, South Africa; Joanneum Research, Austria; the Universidad Nacional Autónoma de México; and the Stockholm Environment Institute, Sweden. The views expressed herein can in no way be taken to reflect the official opinion of the European Union.

\section{CIFOR}

Jl. CIFOR, Situ Gede

Bogor Barat 16115

Indonesia

$\mathrm{T}+62$ (251) 8622-622

$F+62$ (251) 8622-100

E cifor@cgiar.org

\section{www.cifor.org}

Any views expressed in this publication are those of the authors. They do not necessarily represent the views of CIFOR, the authors' institutions or the financial sponsors of this publication. 


\section{Table of contents}

$\begin{array}{lll}\text { Abstract } & \text { v }\end{array}$

1 Introduction 1

2 Challenges in quantifying large-scale farmland acquisitions 2

3 Methodology 4

4 Findings $\quad 4$

4.1 Geographic patterns of investment $\quad 4$

$\begin{array}{ll}4.2 & \text { Sectoral drivers }\end{array}$

5 Reflection on impacts $\quad 12$

6 Conclusions $\quad 15$

7 References 16

Annex

1 Indices compared $\quad 20$

2 Data categories $\quad 20$ 


\section{List of figures, tables and boxes}

\section{Figures}

Primary investment destinations, by total land area acquired 5

2 Origin of non-domestic investments, by total land area acquired 6

3 Investment origin by region, by proportion of total land area acquired 7

4 Primary type of end-market, proportion of total land area 7

5 Primary crop cultivated, proportion of total land area 8

\section{Tables}

1 Examples of 'failed' mega-deals 2

2 Large-scale farmland acquisitions in numbers 5

3 Profiles of farmland acquisitions in Africa larger than 300000 ha 10

4 Land acquisitions and land availability 13

5 Terms of leasehold in selected countries $\quad 14$

\section{Boxes}

1 Comparing different types of large-scale land acquisitions 


\section{Abstract}

In recent years, sub-Saharan Africa has become one of the most significant targets for large-scale land acquisitions for plantation agriculture and forestry. Although investments of this sort can provide much needed capital for Africa's ailing landbased economies, in the context of weak domestic governance of investments and land resources they carry a myriad of socioeconomic and environmental risks. While much has been written on the topic, little empirical evidence is available as to the magnitude, distribution and drivers of large-scale farmland acquisitions in sub-Saharan Africa.

This paper addresses these knowledge gaps by analysing 353 projects in 32 countries in sub-Saharan Africa, covering an area of about 18.1 million ha. It illustrates a high geographic concentration of investments, with two-thirds of the area acquired by large-scale farmland projects located in just seven countries. In some countries, particularly Ethiopia and Ghana, these investments are likely to create significant competition with socially and environmentally valuable land uses, given the comparatively high proportion of 'available' land that has already been acquired since 2005. Moreover, since most lands are leased to investors for renewable periods of 25-99 years, and often originate from the customary domain, this typically implies a long-term alienation of vital livelihood resources.

One of the most significant drivers of these acquisitions was found to be the perception by 'northern' investors, particularly from Europe, of a long-term demand for biofuels in industrialised countries. Another important driver is the demand for food products in 'southern' countries, notably from South Asia and the Middle East, which face domestic land resource constraints and food insecurity. Ultimately, the underlying factors driving farmland investments into sub-Saharan Africa are essentially the same: growing domestic resource scarcity in the face of rising consumption, and declining self-sufficiency for agricultural products. As a result, sub-Saharan Africa is increasingly internalising the costs of global resource scarcity while its gains are exported. This not only calls into question the distributional effects of globalisation, but also the efficacy of global market governance. 



\section{Introduction}

The increasing commercial interest in farmland, particularly for the purpose of plantation agriculture, has become the subject of much debate in the public and political arena. Since 2005, rapidly changing global market conditions have encouraged various actors to seek access to large areas of fertile agricultural land for the cultivation of food crops and biofuel feedstocks. One of the key drivers has arguably been the increasing volatility and inflationary pressures on prices in the food and energy sectors - with the World Food Price Index more than doubling and the Oil Price Index almost trebling between 2005 and 2011 (see Annex 1). Another major driver is the increasing incorporation of biofuels into the energy mix, which, largely in response to the introduction of consumption mandates in industrialised countries and partly due to record oil prices, increased from 35 billion to 86 billion litres per year between 2005 and 2010 (EIA 2011).

This has created a situation where countries with limited resources to ensure self-sufficiency (due to constraints in the availability of oil, water and agricultural land, for instance), but with sufficient capital, are increasingly seeking to secure supplies beyond national boundaries (von Braun and Meinzen-Dick 2009, de Schutter 2011). This strategy is in part an attempt to reduce their exposure to global commodity price shocks. As the geographies of supply and demand become more distinct, the private sector is increasingly positioning itself to capitalise on the trade opportunities this creates (e.g. by shifting to upstream value chain activities overseas). This is reflected in the increasing financialisation of agricultural commodity markets, as illustrated by the rapidly increasing number of outstanding derivative contracts on agricultural commodities (CFTC 2011, Knoepfel 2011) and the growth in specialised agricultural (land) investment funds (GRAIN 2009, Merian Research/ CRBM 2010).

Much of the rush for farmland is concentrated in sub-Saharan Africa. In one of the most comprehensive reports on the phenomena to date, the World Bank (2011) claims that during 20082009, 203 farmland investors expressed an interest in 56.6 million ha globally, of which 39.7 million ha is located in Africa. This demand is estimated to be equivalent to more than 20 years of agricultural land expansion in Africa (Deininger 2011). Preliminary findings from the International Land Coalition (ILC) provide similar conclusions, suggesting that almost two-thirds of the land area that has been 'subject to some form of negotiation' since the early 2000's is found in Africa (Economist 2011, Anseeuw and Taylor 2011). This disproportionate interest in Africa's farmland can be ascribed to its comparative advantages for crop production: the abundance of agro-ecologically suitable and 'available' land and the low cost of land and labour (Fischer et al. 2009, Schoneveld 2010).

While these large-scale agricultural investments could, in theory, make important contributions to Africa's macroeconomic and poverty indices (Poulton et al. 2008, Cotula et al. 2009, World Bank 2011), the intensification of land acquisitions in Africa is increasingly perceived as a 'neo-colonial land grab' by foreign companies and governments, by which the rural poor are being deprived of their livelihood resources (Hall 2011). Since most land in rural Africa is governed by systems of collective ownership under customary, rather than statutory law these concerns are certainly warranted. Despite efforts to extend legal recognition to customary rights in many parts of Africa, customary claims are rarely afforded the same legal protection as formal property rights and, therefore, remain susceptible to expropriation (Alden Wily 2011).

Despite the attention the issue has generated, surprisingly little empirical and non-speculative evidence is available as to the magnitude and distribution of farmland acquisitions in sub-Saharan Africa. This paper contributes to the development of a more evidence-based debate through a systematic categorisation of data on the basis of source reliability. It shows how the perceived long-term demand for biofuels in the EU, and food insecurity in the Middle East and South Asia are the primary drivers of these farmland acquisitions.

Section 2 of this paper highlights some of the key challenges in quantifying the magnitude of farmland acquisitions in sub-Saharan Africa. Section 3 then discusses the methodological approach of the analysis. Section 4 presents key findings and identifies the main geographic patterns and sectoral drivers of farmland acquisitions. Finally, Section 5 reflects on the implications of the findings. 


\section{Challenges in quantifying large-scale farmland acquisitions}

To date limited accurate data has been available as to the magnitude of farmland acquisitions across sub-Saharan Africa. This has made it difficult to accurately gauge the severity and distribution of social and environmental impacts. While previous efforts to quantify the magnitude of farmland acquisitions have offered some valuable insights, they have often suffered from methodological shortcomings, being based on unverifiable accounts or incorporating speculative reports.

One of the main challenges in collecting reliable data is that comprehensive and disaggregated data on large-scale farmland acquisitions is not made publically available by most governments in subSaharan Africa. While the political sensitivity of these land acquisitions often restricts the level of public access to data, in most cases data is not consolidated and maintained in a single location - implying that the government itself is often unaware of its precise scale and scope. Frequently, the ministries that allocate land titles to investors have highly antiquated, non-computerised land registry systems, which complicates the tracing and consolidation of individual entries. In some cases this is further complicated when land administration functions are decentralised (e.g. in the Democratic Republic of the Congo [DRC], Ghana and Nigeria) - this often implies that centralised records are either nonexistent or incomplete. Various other sectoral agencies (e.g. for agriculture, environment or investment) often maintain some records, though the completeness of their data will often depend on the level of direct interaction with investors. However, due to the lack of data coordination between agencies and the limited amount of information collected from investors, basic investor details are typically absent (e.g. the nature of investment, implementation status and nationality).

Given these challenges in accessing data directly from government, most information is obtained from media reports. The data presented by the World Bank (2011), for example, was based exclusively on the media reports posted on the GRAIN blog (http://farmlandgrab.org). However, when scrutinising blog entries for the period used by the World Bank, numerous reports of multimillion hectare mega-deals can be found that never materialised or have turned out to be much smaller in extent than initially claimed (see Table 1 for some examples of such deals). Mega-deals of this sort have frequently been incorrectly cited as fact in other research reports and are readily embraced by the media to illustrate the severity of the 'African

Table 1. Examples of 'failed' mega-deals

\begin{tabular}{|c|c|c|c|}
\hline Investor & $\begin{array}{l}\text { Recipient } \\
\text { country }\end{array}$ & $\begin{array}{l}\text { Area claimed } \\
\text { by the media }\end{array}$ & Reality \\
\hline $\begin{array}{l}\text { Agri SA/Congo } \\
\text { Agriculture (South } \\
\text { Africa) }\end{array}$ & $\begin{array}{l}\text { The Republic } \\
\text { of the Congo }\end{array}$ & $\begin{array}{l}10.0 \\
\text { million ha } \\
\text { (Reuters } \\
\text { 2009a) }\end{array}$ & $\begin{array}{l}\text { The contract signed in March } 2011 \text { by Congo Agriculture, an } \\
\text { Agri SA affiliated company, covered } 80000 \text { ha. The original } \\
\text { Reuters (2009a) report appears to have misquoted an Agri SA } \\
\text { representative, who was ostensibly referring to the Republic of } \\
\text { the Congo's land availability. }\end{array}$ \\
\hline ZTE (China) & $\begin{array}{l}\text { The } \\
\text { Democratic } \\
\text { Republic of } \\
\text { the Congo }\end{array}$ & $\begin{array}{l}2.8 \text { million ha } \\
\text { (Associated } \\
\text { Press 2008) }\end{array}$ & $\begin{array}{l}\text { According to the concession contract signed between ZTE } \\
\text { and the Ministry of Agriculture, } 100000 \text { ha were allocated } \\
\text { (Government of the Democratic Republic of the Congo 2007). } \\
\text { The information source for the Associated Press (2008) report } \\
\text { was not specified. }\end{array}$ \\
\hline $\begin{array}{l}\text { Wuhan Kaidi } \\
\text { (China) }\end{array}$ & Zambia & $\begin{array}{l}2.0 \text { million ha } \\
\text { (Reuters } \\
\text { 2009b) }\end{array}$ & $\begin{array}{l}\text { Three leasehold titles were obtained covering } 79300 \text { ha. } \\
\text { While the company sought to acquire much larger areas of } \\
\text { land, most chieftaincies refused to alienate land to the project } \\
\text { (German et al. 2011). }\end{array}$ \\
\hline $\begin{array}{l}\text { Daewoo Logistics } \\
\text { (South Korea) }\end{array}$ & Madagascar & $\begin{array}{l}1.3 \text { million ha } \\
\text { (Reuters } \\
\text { 2008a) }\end{array}$ & $\begin{array}{l}\text { While negotiations were well advanced, these came to an } \\
\text { abrupt end when the standing government was ousted in } \\
2009 \text { - according to some observers, the imminent land deal } \\
\text { contributed to this (Ullenberg 2009). }\end{array}$ \\
\hline
\end{tabular}


land grab'. Considering the tendency of the media to over-inflate and misrepresent the status and size of some of these investments, caution should be used when basing analyses on such sources without proper triangulation.

Another methodological challenge relates to how different sectors should be treated in an aggregated analysis of this sort, particularly when the analysis is based around area figures. For example, as discussed by Zoomers (2010), the commercial pressures on land are also prevalent in the mining, tourism and conservation sectors. Since the underlying drivers and the innate environmental and developmental impacts of large-scale land acquisitions are highly specific to different sectors and business models, comparing sectors on the basis of area figures does not enable us to draw meaningful conclusions (see Box 1 for a more detailed discussion). For that reason, this analysis focuses exclusively on largescale land acquisitions in plantation agriculture and plantation forestry, which are similar in their developmental impacts.

\section{Box 1. Comparing different types of large-scale land acquisitions}

Besides plantation agriculture and forestry, large-scale land acquisitions are prevalent in a number of different sectors, such as real estate, infrastructure, industry, conservation, logging and mineral exploitation. Since the amount and type of land sought and the manner in which that land is to be used differs in accordance with the intended purpose, it is difficult to generalise as to the inherent opportunities and risks of land-based investments.

For example, in cases of land allocated for spatially expansive activities, such as mineral prospecting or industrial logging, the extent of their impact on land use and rights of access tends to be more limited than plantation production systems. In industrial logging concessions in Africa, concessionaires typically only have the right to harvest timber (selectively) and are often subject to a harvesting quota (e.g. allowable annual cut). Unlike plantations, where in most cases, though not all, the entire bundle of customary rights is affected, in logging concessions this is usually limited to timber withdrawal rights (Karsenty 2011). On the other hand, since the area under commercial logging concessions is manifold larger than that under plantation production systems, their impact, while less intensive, may certainly be more extensive. For example, in central Africa 30-40\% of remaining forest is under concession, with numerous individual companies holding rights to areas covering several millions of hectares (Karsenty 2007, Clark et al. 2009).

In the case of mineral prospecting, concessionaires only have the right to prospect for certain minerals, typically affecting only a fraction of the concession area. For economic reasons, trenching and exploratory drilling activities typically take place on small and carefully selected areas, usually identified through geological surveys. In mineral rich countries, large areas are typically allocated for this purpose. In Zambia, for example, the government allocated 23.4 million ha for prospecting during 2005-2010, equivalent to almost one-third the country's total surface area (Government of Zambia 2010a). Hence, for logging and mineral prospecting concessions the intensity of land use change tends to be less severe than plantation production systems, since competition with other land uses is more limited and many customary access rights are preserved. Similarly, land privately acquired for conservation (e.g. for the purpose of ecotourism and carbon finance) is unlikely to entail environmentally detrimental land use changes and is more likely to have had some form of protected status prior to acquisition (Carter et al. 2008), thus reducing, though certainly not eliminating, the risk of conflict with customary land uses.

For many types of investment pertinent to the land grab debate, such as mineral extraction, real estate, industrial development, and much of the tourism sector (with the exception of private conservation areas), the average allocated area of land tends to be a fraction of that for large-scale plantations. However, that does not imply that the impact of these types of investments is more limited. For example, while the degree of direct land use change and impact on land use rights may be more confined for such investments, indirect impacts may be more profound as a result of high levels of in-migration, economic spill-overs, increasing competition for land, and pollution. Area data for such sectors is, therefore, not likely to be a useful indicator of impact, especially when applied for purposes of cross-sectoral comparison or aggregation. 


\section{Methodology}

This analysis is based on a dataset of projects developed from October 2008 to November $2011 .^{1}$ The analysis includes only those projects from the forestry and agricultural sector that engage in plantation production models. It excludes agricultural and forestry investments adopting smallholderoriented business models (e.g. tenant farming or out-grower schemes), industrial logging concessions, and investments in other land-intensive/extensive sectors. The projects incorporated into the analysis involve the transfer of use or ownership rights over contiguous areas of land larger than 2000 ha. $^{2}$ Only land transfer agreements that were entered into after January 2005 are included. This date was taken as the cut-off date due to the significant change in global market conditions for relevant commodities since that time.

In recognition of the methodological challenges discussed in Section 2, collected data was divided into three quality categories (see Annex 2 for a more detailed discussion). Category 1 data has the highest level of accuracy and is derived exclusively from verifiable sources. Category 2 data includes data that could not be verified, though is considered to be reliable by meeting certain criteria. Category 3 data includes all miscellaneous data and is omitted from this analysis. In this manner, the use of speculative and unverifiable data is minimised and a more accurate picture of the nature and magnitude of large-scale farmland acquisitions can be derived.

Although some companies included in this analysis have since had their rights to land revoked, gone bankrupt, or have permanently ceased operations, data from these projects has been incorporated, since the land rarely reverts back to its previous ownership status. Typically, projects are either acquired by other operators, or the land is subleased, reallocated by the government for other commercial purposes, or is permanently alienated from the customary domain (e.g. by having been reclassified as state land).

1 The types of data maintained in the project dataset include, though are not limited to: investor(s') name(s); country of investment; country of origin of 'lead investor'; mode of market entry; location; area of land transferred; type of land acquired; nature of land transfer agreement; area of land developed; date of transfer; crops and/or tree species cultivated; target market; and category of data quality.

2 Following the definition of large-scale land acquisitions used by Rahmato (2011).
Although this study seeks to overcome some of the key methodological challenges in quantifying large-scale farmland acquisitions, it recognises that methodological limitations remain. For example, it may under-represent domestic projects. These may be less 'publically visible' and less likely to be documented by the public administration, as they are often less closely monitored than foreign investments. Additionally, investments in some countries may not be captured as well as in others; due to decentralised information management, controls on public access to information, or weaker regulatory oversight and/or administrative capacity.

\section{Findings}

\subsection{Geographic patterns of investment}

A total of 353 projects larger than 2000 ha were identified across 32 countries in sub-Saharan Africa, covering an area of 18104896 ha. This is equivalent to about $8.3 \%$ of the annual area harvested in subSaharan Africa (calculated from FAOSTAT) ${ }^{3}$. A total of 297 projects (15 $094911 \mathrm{ha}$ ) fulfil Category 1 requirements, and $56(3009$ 985) fulfil Category 2 requirements. ${ }^{4}$ Within Category 1 , seven projects (734 $718 \mathrm{ha}$ ) had conditional leasehold agreements. The median project size is 18512 ha and the mean project size $50856 \mathrm{ha}$. A total of 53 projects exceeded 100000 ha, with the largest project included in this analysis being the 892000 ha Farm Block Development Programme initiated by the Government of Zambia (see Table 2 for profiles of some of the major farmland acquisitions).

As is illustrated by Figure 1, the areas of land acquired vary significantly between countries. The seven countries (Ethiopia, Ghana, Liberia, Madagascar, Mozambique, South Sudan and Zambia) where more than 1 million ha have been acquired (for both category 1 and 2 data) constitute $65.7 \%$ of the total area acquired.

3 FAOSTAT provides time-series and cross-sectional data relating to food and agriculture for some 200 countries. http://faostat.fao.org/.

4 For the purpose of this analysis, a legal entity constitutes a project. Therefore, should one company be developing numerous plantations, each with different legal partners, then each plantation is considered a separate project. By this definition, therefore, if the same legal entity, with the same partners, is developing numerous plantations, then these plantations are all considered to be part of a single project. 


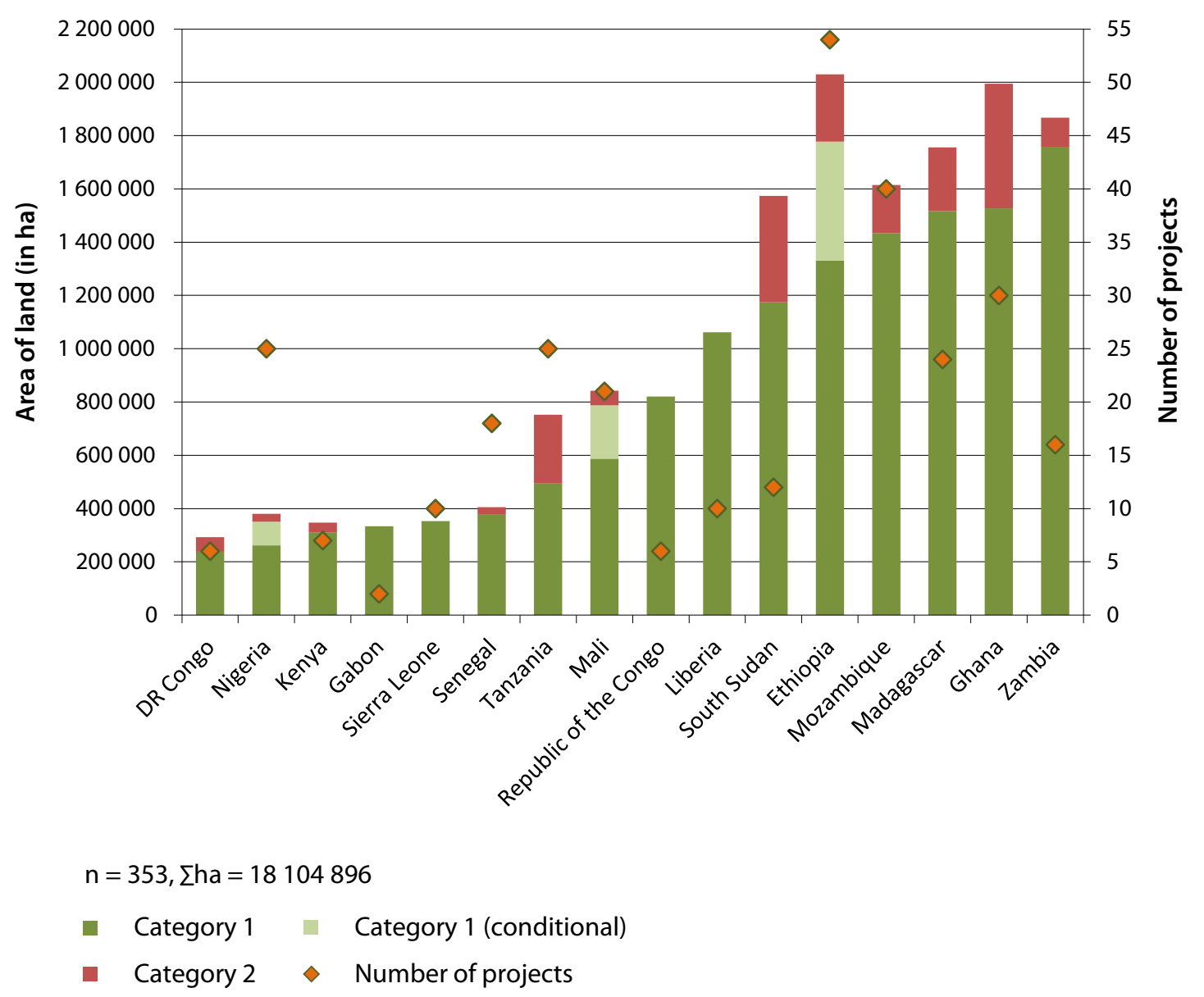

Figure 1. Primary investment destinations, by total land area acquired

Table 2. Large-scale farmland acquisitions in numbers

\begin{tabular}{lr}
\hline Variable & Area (in ha) \\
\hline Total area acquired & 18104896 \\
Category 1 data (total) & 15094911 \\
Category 1 data (conditional) & 734718 \\
Category 2 & 3009985 \\
Mean & 50856 \\
Median & 18512 \\
\hline
\end{tabular}

While a correlation might be expected between the area of land acquired and a country's surface area, or the area of available agro-ecologically suitable land, no statistical relationship is discernible. For example, countries with relatively small surface areas and scarcity of suitable land (e.g. Ghana, the Republic of the Congo and Liberia) have become key recipients of farmland investments, while other countries with abundant reserves of land (e.g. Angola and the DRC) have not become important investment targets. Additionally, there is no statistically significant correlation with quality of governance, as illustrated by the magnitude of investments in politically unstable countries, such Ethiopia and Madagascar (as per the Worldwide Governance Indicators) ${ }^{5}$, and countries that are known to be particularly difficult to conduct business in, such as the Republic of the Congo (as per the Doing Business ranking) ${ }^{6}$. Clearly, generalisations do not do justice to the complex interplay of factors that shape a country's attractiveness as a farmland investment destination. Comprehensive research would be required to

5 The Worldwide Governance Indicators (WGI) is a World Bank project which reports aggregate and individual governance indicators for 213 economies over the period 1996-2010, for six dimensions of governance. http://info.worldbank.org/ governance/wgi/index.asp.

6 An International Finance Corporation and World Bank project ranking economies on their ease of doing business. http://www.doingbusiness.org/rankings. 


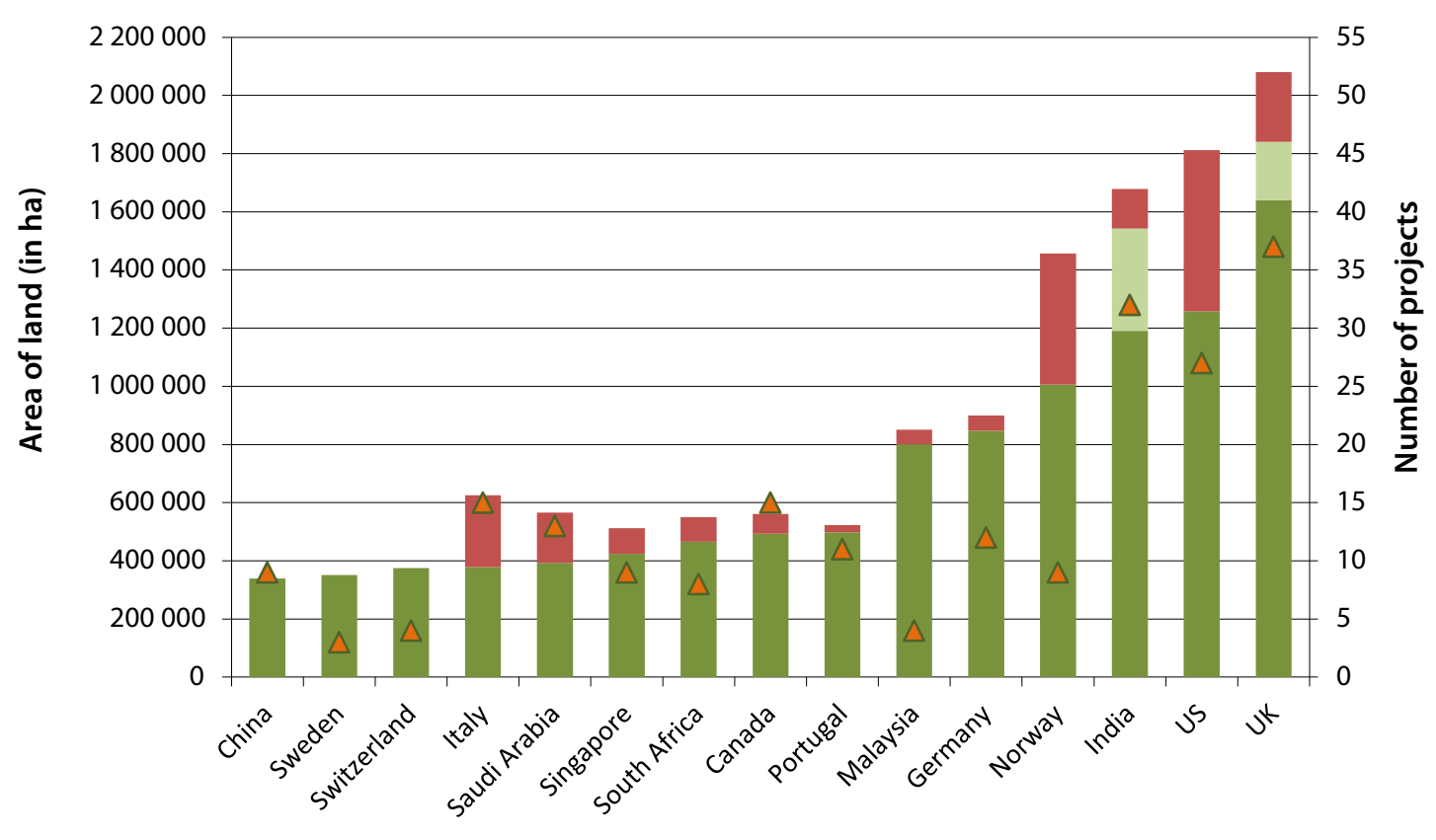

$\mathrm{n}=275$, $\Sigma \mathrm{ha}=15395742$

$\begin{array}{ll}\text { - Category } 1 & \text { Category } 1 \text { (conditional) } \\ \text { - Category } 2 & \Delta \text { Number of projects }\end{array}$

Figure 2. Origin of non-domestic investments, by total land area acquired

Note: When projects are registered in offshore financial centres despite being headquartered elsewhere, the latter is considered to be the origin of investment. Furthermore, where projects have originated in the form of a partnership or joint venture agreement, only the origin of the investor with the majority share is included.

unravel the key determinants that shape countries' relative attractiveness. What most of the key investment destinations have in common though is a strong government commitment towards developing commercial agriculture - reflected particularly in the institutional support and incentives afforded to foreign agricultural investments.

With regards to investor origin, few lead investors are domestic. Of the 331 projects for which investor origin could be established, only 55 projects (covering 2358235 ha or $13.3 \%$ of the total area acquired) had a local operator leading the development.

With 37 projects covering 2079823 ha the United Kingdom was found to be the largest investor, followed by the United States, India and Norway (Figure 2). From a regional perspective, investments from Europe dominate, accounting for 120 projects covering 7068041 ha $(39.8 \%$ of the total area acquired). ${ }^{7}$ This is followed by Asia with 59 projects covering $3709573 \mathrm{ha}(20.9 \%$ of the total area acquired) (Figure 3). Brazil is engaged in a number of projects; although Latin America as a region, endowed with relatively abundant agro-ecologically suitable land, is a comparatively marginal investor; this too applies to Australasia. ${ }^{8}$

7 For the purpose of this analysis, 'Europe' constitutes the 27 countries of the European Union (EU) plus Norway and Switzerland.

8 Though currently limited, agricultural investments from Brazil are expected to grow, particularly into Mozambique. In August 2011, the Mozambican Minister of Agriculture, for example, said Mozambique could make up to 6 million ha of land similar to that of the Cerrado available to Brazilian farmers (Reuters 2011a). 


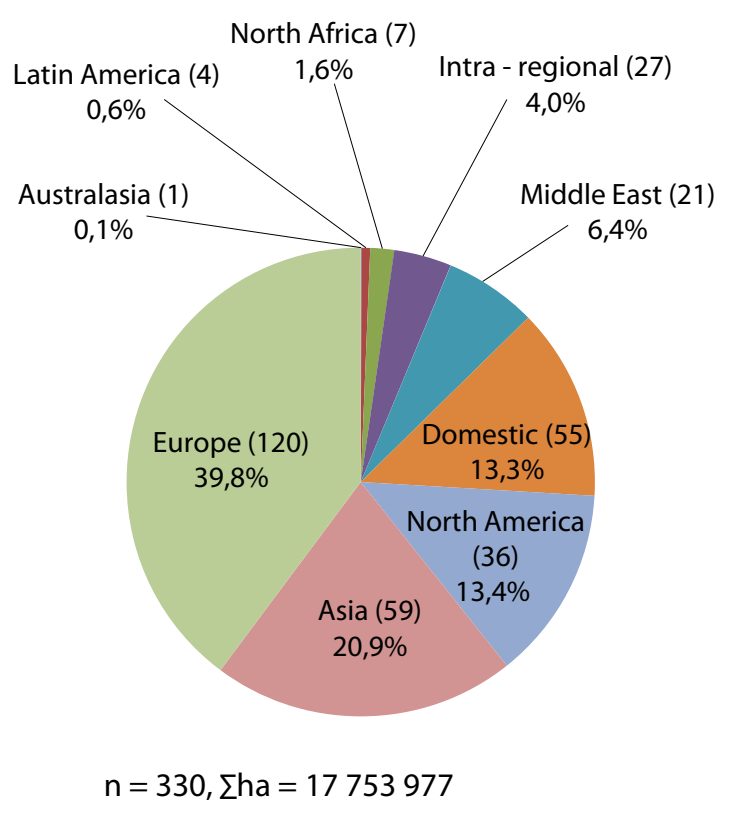

Figure 3. Investment origin by region, by proportion of total land area acquired

Note: The number of projects is in brackets.

While Asian investors play an important role, China is not a dominant investor in plantation agriculture in Africa, in contrast to how it is often portrayed (see, for example, AFP 2011, Economist 2011, New Scientist 2011, Reuters 2011b).

\subsection{Sectoral drivers}

\section{Biofuel feedstocks: The leading driver of large-scale farmland acquisitions}

The most important strategic driver of large-scale farmland acquisitions documented in this analysis is the perceived opportunities in the biofuel sector. For example, of the 329 projects that specified their objectives, 188 projects acquired land with plans to cultivate crops for the purpose of eventually producing biofuel feedstocks. These projects account for 11220 334ha (approximately 63.0\% of the total area of land acquired in sub-Saharan Africa) (Figure 4). While certain biofuel projects, particularly the larger projects cultivating multi-use crops, target both food and biofuel end-markets, the vast majority of projects (158 projects, covering 7647 859ha) were conceived to service the biofuel sector. In contrast, only 92 projects (covering 4 410649 ha) target exclusively the food end-market, and 24 projects (covering $1604142 \mathrm{ha}$ ) the wood products end-market (e.g. timber, pulp and paper).
Very few projects targeted the fibre sector (e.g. textiles) or 'other' sectors, such as latex, spice, feed and pharmaceutical, collectively accounting for 25 projects (covering 569419 ha).

The majority of projects in the biofuel sector were attracted by the purported economic potential of the oil-seed bearing shrub Jatropha Curcas (jatropha) (Figure 5). Particularly during 2007-2008, jatropha was much touted due to its high ecological adaptability and its perceived potential to generate high yields under low management conditions. This was despite it being a largely undomesticated crop for which little agronomic experience has been gained in cultivating it on an industrial scale. Goldman Sachs even promoted it as being the cheapest feedstock for biofuel production (Wall Street Journal 2007).

A total of 89 projects set out to cultivate jatropha, collectively having acquired at least $5376075 \mathrm{ha}$ (constituting $47.9 \%$ of the land acquired by biofuelrelated projects). Despite the initial hype, investors rarely succeeded in achieving anticipated yields, which ultimately resulted in many projects going bankrupt, temporarily suspending operations, downscaling, or shifting to the cultivation of more

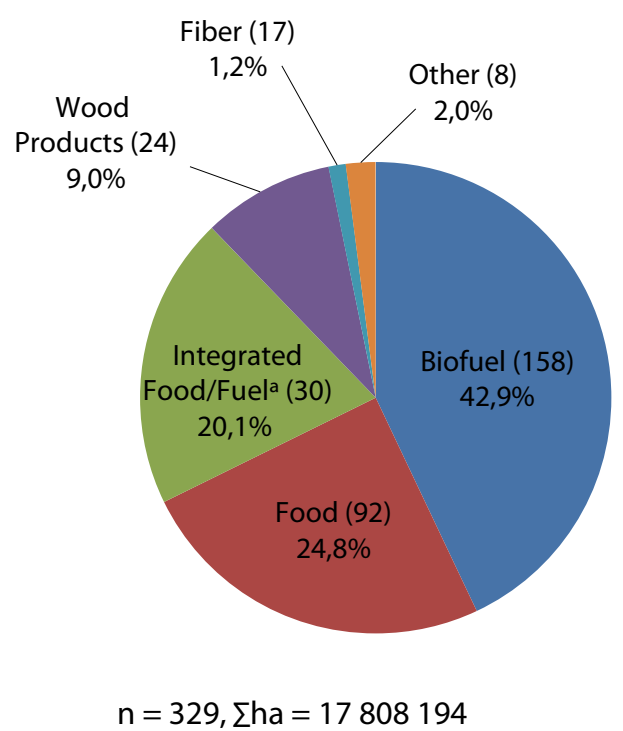

Figure 4. Primary type of end-market, proportion of total land area

a Integrated food/fuel projects are projects that in addition to cultivating crops as biofuel feedstocks, target food end-markets as a secondary distribution outlet; typically the case for certain sugarcane and oil palm projects.

Note: The number of projects is in brackets. 


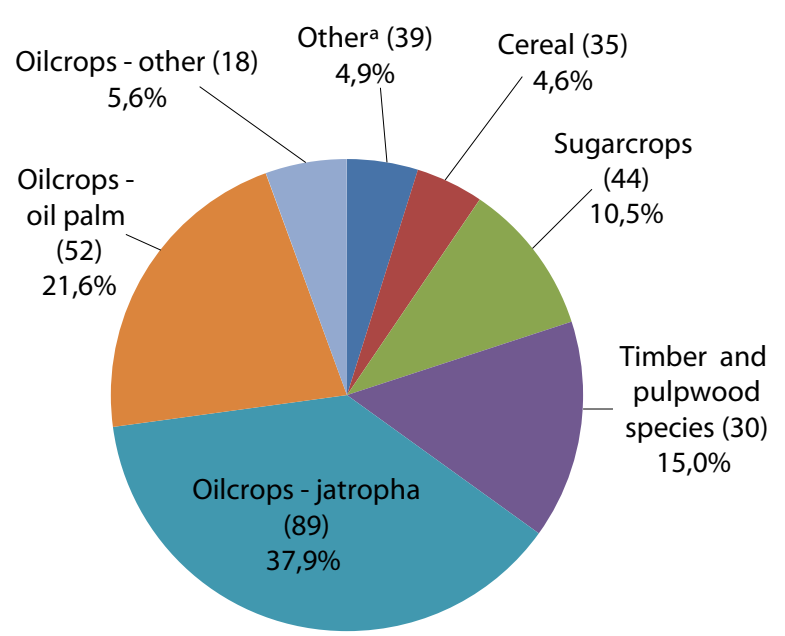

$\mathrm{n}=308, \Sigma \mathrm{ha}=14183844$

Figure 5. Primary crop cultivated, proportion of total land area

a Other crops include tea, rubber, banana, pineapple, paprika, tomato, cassava, sisal and cotton.

Note: The number of projects is in brackets. Projects that plan to cultivate a number of different crops are only included in these figures when they specify that they are primarily targeting the cultivation of one crop. Many large projects that cultivate a wide range of different crops are therefore excluded.

conventional crops. At least nine projects, covering an area of 455956 ha, were confirmed to have completely ceased operations. ${ }^{9}$ The fact that most jatropha investors are poorly capitalised start-up companies may also have contributed to jatropha's poor performance. Even for other feedstocks, few biofuel projects are led by established players in energy or agrobusiness, illustrating the critical enabling role of private equity and venture capital in propelling Africa's biofuel sector. ${ }^{10}$

Other key feedstocks for biofuel projects in subSaharan Africa include oil palm, sugarcane, cassava, and an array of oil-seed crops such as castor, sunflower and pongamia. Land has been acquired for biofuel projects in 24 countries, with the largest

9 Notable failures include Bioshape (Netherlands), Energem (UK), ESV (UK), and, as of August 2011, the much acclaimed Sun Biofuels (UK).

10 The only well-established companies active in the African biofuel sector are Api Nova Energia (Italy), ENI (Italy), Ferrostaal (Germany), Fri-el Green (Italy), Galp Energia (Portugal), Odebrecht (Brazil), SEKAB (Sweden), Tata Chemicals (India) and Wuhan Kaidi (China). areas of land located in Ethiopia (18 projects, $807390 \mathrm{ha}$ ), Ghana (23 projects, $1241400 \mathrm{ha}$ ) and Madagascar (19 projects, 1329600 ha). Although it hosts a smaller average farm size, Mozambique boasts the largest number of projects (28 projects, 506255 ha). Only in Ethiopia and Mozambique did the government actively pursue and promote biofuelrelated investments.

The primary underlying driver for these biofuel investments appears to be the opportunities in key export markets, notably North America and the EU. Driven primarily by blending mandates, in the medium term these markets are anticipated to become the largest net importers of biofuels in the world (Schoneveld 2010). This is clearly an outlook that biofuels investors are banking on. This is also reflected in the fact that the three countries anticipated to become the largest net importers of biofuels in the EU by 2020, the UK, Germany, and Italy, are also the most active EU biofuel investors, both in terms of area acquired and number of projects (with a total of 48 projects covering 3267 $029 \mathrm{ha})^{11}$. With biofuel projects accounting for $88.9 \%$ of these investors' combined acquired area and $76.4 \%$ of their projects, the opportunities in these markets are clearly their most important investment driver.

On aggregate, 105 biofuel projects were led by investors from North America and the EU, covering an area of 6667091 ha, equating to $37.5 \%$ of the entire area acquired and $31.2 \%$ of all projects. These figures illustrate the comparatively significant role of the North American and EU biofuel demand (linked to domestic blending mandates) in driving large-scale farmland acquisitions in Africa.

\section{The rise of the oil palm mega-estate}

Another notable development is the rapid rise of large-scale oil palm projects. Oil palm is the most productive oil-seed crop, and investment prospects have been rosy over the previous two years, as the market has been buoyed by high prices and rapidly growing demand from emerging economies, such as India and China. Since 2005, mostly as of 2009, 52 projects have acquired 3060396 ha for oil palm

11 According to their National Renewable Energy Action Plans (NREAP), the UK, Germany, and Italy expect that total imports will constitute $88 \%, 59 \%$ and $39 \%$ of their total biofuel consumption by 2020 , respectively. The UK is anticipated to become the EU's largest biofuel importer by 2020, expected to account for $34 \%$ of EU biofuel imports (Atanasiu 2010). 
cultivation across sub-Saharan Africa. With suitable land comparatively abundant and cheap, oil palm investors are increasingly seeking to gain access to land in the tropical rainforest areas of sub-Saharan Africa, particularly in Congo basin countries and the coastal areas of west Africa. More than half the acquired area is located in three countries: Liberia (940 735 ha), Sierra Leone (311 617 ha), and the Republic of the Congo (580 000 ha). Large-scale oil palm cultivation is also expected to increase considerably in Cameroon: in addition to the 90 068 ha that has already been acquired for oil palm cultivation since 2005, two high profile deals for 200 000 ha and 300000 ha of land are currently under negotiation (Financial Times 2011, Reuters 2011c, Sime Darby personal communication). Although this recent trend is in part driven by biofuel investments from North America and the EU, since early 2010 major Asian oil palm conglomerates, such as Bakrie Sumatera (Indonesia), Olam (Singapore), Sime Darby (Malaysia) and Wilmar (Singapore) have shown increased interest. With well-established networks in the food and pharmaceutical industry, such companies have made only limited efforts to diversify into biofuel production. ${ }^{12}$

As suitable land in the largest oil palm growing countries (Indonesia and Malaysia) becomes more scarce and more expensive (even more so with the implementation of Indonesia's deforestation moratorium), these companies are increasingly encouraged to expand their geographic coverage. ${ }^{13}$ According to a senior representative from Sime Darby, an added advantage of operating from Africa is the physical proximity to European markets and the ability to circumvent the prohibitively high duties that apply to crude palm oil exports from Malaysia and Indonesia.

Of farmland acquisitions larger than 300000 ha, 3 out of 10 are being developed by Asian oil palm companies, with another 2 companies also planning

12 Arguably, this limited interest in oil palm-based biodiesel production is also due to the reluctance of their home governments to enforce biodiesel blending mandates, the comparatively high global price of crude palm oil over recent years, and the imposition of regulatory obstacles in accessing the EU biofuel market (created by the Renewable Energy Directive that came into force in 2011) (Schoneveld et al. 2010).

13 The typical rental rate in Indonesia and Malaysia is US \$200-400 per ha (Olam 2010, World Bank 2011); while in Africa, oil palm companies are leasing land for rates typically less than US $\$ 5$ per ha (see Section 5 for a discussion). on cultivating oil palm within multi-crop estates (Table 3).

\section{Southern investments in food crop production}

Investments in crop production for the food market are significantly more limited than for the biofuel market. Besides the expansion of oil palm plantations by Asian companies, the most significant number of investments have targeted sugarcane and rice production. Sugarcane (mostly for producing crystallised sugar and ethanol for beverages) accounts for 16 projects (covering $694503 \mathrm{ha}$ ), and rice production, 26 projects (covering $562808 \mathrm{ha}$ ). Although some of the larger multi-crop estates cultivate non-rice staples (such as wheat, maize and tubers), the number of investments that primarily target those crops is negligible (only 10 projects, covering $101292 \mathrm{ha}$ ).

While projects from North America and the EU were clearly dominant in the biofuel sector, in the food sector they are surprisingly absent. Of the 92 food projects, only 22 projects (covering 924905 ha) originated from North America and the EU. These types of investment are more frequently made by companies from other southern economies. Several chronically food-insecure countries with high domestic pressures on suitable lands have been acquiring farmland, typically supported by home-country incentives for outward investment. Food investment from India, Libya and Saudi Arabia alone account for 23 projects, covering 1167612 ha in sub-Saharan Africa. Large Indian agrobusinesses in particular, such as Karuturi Global, Neha International and the Siva Group, are rapidly expanding across Africa. As a result of high population pressures, comparatively high land prices, regulatory obstacles and growing water shortages it is becoming prohibitively difficult to gain access to large contiguous areas of land in India (see Rowden 2011 and NewsClick 2011 for a discussion).

Similarly, well-capitalised Arab investment companies such as Citadel Capital (Egypt) and Foras Investment (Saudi Arabia), facing similar domestic constraints, are expanding their land banks in Africa for food crop cultivation.

Faced by growing barriers to accessing farmland at home, commercial farmers from South Africa are also actively negotiating access to farmland beyond national boundaries, predominantly through the commercial farmer organisation Agri SA. Land has already been allocated to its members in the Republic 
Table 3. Profiles of farmland acquisitions in Africa larger than 300000 ha

\begin{tabular}{ll}
\hline Details & Company overview \\
\hline $\begin{array}{l}\text { Name: Farm Block Development } \\
\text { (FBD) Programme }\end{array}$ & The FBD programme was conceived as part of Zambia's new strategic thrust to \\
Origin: Zambia & promote commercial farming, following the adoption of the National Agricultural \\
Investor country: Zambia & Policy in 2004. For this purpose, the government acquired, through voluntary \\
Area of land: 892000 ha & transactions, 892000 ha across its 9 provinces, with each farm block covering \\
& $45000-147750$ ha. Each block is partitioned into different estates, with one 'anchor \\
& estate' (about 10000 ha), a number of 'commercial estates' (about 2000-4000 ha), \\
& and a few hundred 'satellite farms' (20-1000 ha). In each farm block, the government \\
& will provide basic infrastructure (e.g. roads, dams, electricity). The guiding \\
& philosophy behind the FBD programme is to develop greater horizontal and vertical \\
& linkages in the agricultural sector through geographic clustering. Progress has been \\
& slow though, with only one farm block actively seeking investors.
\end{tabular}

Name: Nile Trading \& Development (NTD)

Origin: US

Investor country: South Sudan

Area of land: 600000 ha

\author{
Name: Ferrostaal AG \\ Origin: Germany
}

Investor country: Zambia

Area of land: 510183 ha

Name: Atama Plantation SARL

Origin: Malaysia

Investor country: The Republic of the Congo

Area of land: 470000 ha

\author{
Name: GEM Biofuels \\ Origin: UK
}

Investor country: Madagascar

Area of land: 452500 ha
Sources: Government of Zambia (2005), Government of Zambia (2009), Ministry of Agriculture (personal communication), ZDA (personal communication)

NTD is an affiliate of the Texas-based holding company Kinyeti Development, founded by a former US ambassador. In 2008, NTD entered into a 49 year lease agreement with the Mukaya Payam Cooperative (a territorial subdivision of South Sudan) for 600000 ha of 'forested land' (extendable to 1 million ha). As per the agreement, NTD is permitted, amongst others, to harvest all trees without limitation, cultivate oil palm and jatropha, engage in the exploration and extraction of any minerals, and sublease any area of the land. Planned activities though appear to be focused on biofuel development. From 2012 onwards, $40 \%$ of profits are to be shared with the cooperative.

Sources: Government of South Sudan (2008), Deng (2011), Kinyeti (2011)

Ferrostaal, formerly known as MAN Ferrostaal, is 70\% owned by the United Arab Emirates-based International Petroleum Investment Company (IPIC). Following a 2009 visit to Zambia by an official UAE delegation, including IPIC, Ferrostaal signed a memorandum of understanding with the Zambia Development Agency (ZDA) to develop jatropha plantations and a biodiesel refinery with an investment of US \$500 million. According to its environmental brief and Cadastral maps, in 2010 the ZDA provided Ferrostaal with 11 leasehold agreements for a combined area of 510183 ha in Mpika District, Northern Region - though only 303749 ha appear to have been surveyed. Ferrostaal is currently conducting jatropha trials through its South African implementation partner, Deulco.

Sources: Government of Zambia (2010b), District Council of Mpika (personal communication), ZDA (personal communication)

In December 2010, the Malaysian company Atama Plantations signed a leasehold contract covering 470000 ha, for the development of oil palm plantations in the departments of Cuvette and Sangha in northern Congo, following a trip by Congolese officials to Malaysia. The company is planning to invest US $\$ 300$ million into the project over the coming 15 years. The company's background is mysterious, with the company and its senior executives not appearing to be established players in the Malaysian palm oil sector.

Sources: Daily Motion (2010), IOI Group (2010)

GEM BioFuels was incorporated in 2004 in the Isle of Man, and has been listed on the AIM stock exchange since 2007. The company has entered into 50-year lease agreements with 18 local communities in southwest Madagascar for the exclusive right to establish jatropha plantations over 452500 ha. With approximately 55700 ha under cultivation by the end of 2010, it has the largest known area planted with jatropha in Africa. The company has a 10-year off take agreement with Australia's Natural Fuel Limited (NFL) to supply 55\% of its crude jatropha oil to NFL's biodiesel facility in Singapore.

Sources: NFL (2008), Ullenberg (2009), GEM Biofuels (2010) 
Tabel 3. Continued

\begin{tabular}{ll}
\hline Details & Company overview \\
\hline Name: Sime Darby Liberia & One of Malaysia's largest conglomerates, Sime Darby, signed a concession \\
Origin: Malaysia & agreement with the Government of Liberia in 2009 for the development of oil palm \\
Investor country: Liberia & and rubber plantations. The agreement involves the allocation of 4 concessions, \\
Area of land: 311187 ha & covering 311187 ha, under a 63-year leasehold title. On this land, 220000 ha are to \\
& be developed into Sime Darby managed estates and 44000 ha into an out-grower \\
& scheme. 120000 ha was previously exploited for rubber by Kumpulan Guthrie \\
& Berhad, before it was abandoned in 2001 as a result of the civil war. Sime Darby \\
& plans to invest US $\$ 3.1$ billion in the first 15 years. In 2011, the company announced \\
& plans to invest US $\$ 2.5$ billion in 300000 ha in Cameroon, though, despite ongoing \\
& negotiations, no leasehold agreements have yet been signed.
\end{tabular}

Sources: Government of Liberia (2009), Financial Times (2011), Sime Darby (personal communication)

Name: Karuturi Global Origin: India

Investor country: Ethiopia

Area of land: 310800 ha

Name: ScanFarm AS

Origin: Norway

Investor country: Ghana

Area of land: 303750 ha

Name: Olam Palm Gabon Origin: Singapore/Gabon Investor country: Gabon Area of land: 300000 ha
Incorporated in Bangalore, India, in 1994, Karuturi Global is the largest producer of cut roses in the world, with established horticultural operations in Ethiopia, India and Kenya. With its more recent forays into plantation agriculture, the company has become the object of much media attention for entering into long-term leasehold agreements with the Government of Ethiopia in 2008 - for 11700 ha (30 years) and 138000 ha (50 years). The 11700 ha area is yet to be demarcated due to ongoing land conflicts, and will be reduced in extent to 10800 ha to avoid resettlement. In the case of the 138000 ha area, involving land located in a national park, the contract was renegotiated by the federal government in 2010 . Under the new terms the company would gain direct access to $100000 \mathrm{ha}$, and gain access to another 200000 ha upon the full development of the initial 100000 ha by late 2012. The company plans to cultivate oil palm, sugarcane, cereal and pulses. To date cultivation activities have focused largely on maize, with approximately 9500 ha cultivated in the 2011 season.

Sources: Government of Ethiopia (2010), Karuturi Global (2011), Gambella and Oromiya Investment Agency (personal communication), Karuturi Global (personal communication)

ScanFarm AS, formerly known as ScanFuel AS, started jatropha cultivation in the Ashanti region of Ghana in 2008. The Norwegian biofuel start-up indicated that it had signed a 50-year agreement with the Agogo Traditional Council for access to about 303750 ha - an area consistent with a sketch map included in ScanFarm's environmental impact assessment. This area appears to comprise part of the Kogyae Nature Reserve and conflicts with other concessions, raising questions as to how well the land has been demarcated. At conception, the company planned to develop $60 \%$ of the area with biofuel feedstock and $30 \%$ with food crops, investing US $\$ 500$ million in the first 10 years. To date, ScanFarm has only obtained an Environmental Permit for a 20452 ha 'pilot plot'. Due to disappointing jatropha yields and a change in strategic direction, the company turned to maize and soya cultivation in 2010, having approximately 1500 ha under cultivation.

Sources: Government of Ghana (2008), Reuters (2008b), Ghana Investment Promotion Commission (personal communication), ScanFarm (personal communication)

Olam Palm Gabon is a joint venture established in 2010 between the Singaporebased commodity trader Olam International (70\%) and the Government of Gabon (30\%). As part of the agreement, the government provided a land bank of 300000 ha. For Phase 1, to be completed in 2016, the government awarded three 50-year leasehold agreements for an area totalling 51920 ha in Gabon's forest zone. With most of this area considered to be of high conservation value, only 8334 ha is suitable for oil palm cultivation according to Roundtable on Sustainable Palm Oil (RSPO) requirements. Olam also recently acquired a 300000 ha logging concession and is developing a special economic zone for processing the timber. In a joint venture with the Wilmar Group, Olam established Nauvu Investments in 2007, as a vehicle for investments in African oil palm and rubber plantations. Nauvu Investments also has a stake in Côte d'Ivoire's largest oil palm plantation company PALM CI. 
of the Congo, a framework agreement has been signed in Mozambique, and negotiations are ongoing in Ghana, South Sudan and Zambia.

Although a number of major investments in food production can be found in countries such as Ghana, Mozambique, Nigeria, South Sudan and Zambia, by far the most significant number are located in Ethiopia. A total of 21 projects, covering 990798 ha, exclusively targeting the production of food crops, have acquired land in Ethiopia. Although this can be partly attributed to the active role of the Ethiopian government in attracting investments in commercial agriculture, the country's increasingly close economic and diplomatic ties to India are certainly a contributing factor. Of Ethiopia's 21 food projects, 10 are being developed by Indian investors, constituting $48.4 \%$ of the total area acquired for large-scale food projects in Ethiopia. ${ }^{14}$

\section{Nordic investments in plantation forestry}

In contrast to plantation agriculture, plantation forestry has not been a major driver of farmland acquisitions, with 30 projects covering an area of 2123265 ha. Most of these forestry projects target the timber and pulp and paper end-markets, with 6 projects targeting the biofuel market (predominantly in the form of electricity generation or briquette production). The most frequently cultivated tree species are, in descending order, eucalyptus, pine, acacia and teak.

Of these 30 projects, 22 are led by investors from North America and the EU, covering 1939605 ha (91.4\% of the total area acquired for plantation forestry). Companies from Nordic countries with a long history of plantation forestry (for export markets) are especially active in plantation forestry in Africa, with projects from Denmark, Norway and Sweden responsible for the acquisition of 1225905 ha. Some of the largest projects are being developed by African Plantations for Sustainable Development (Norway), the Global Solidarity Forest Fund (Sweden) and Green Resources (Norway).

While forestry projects were documented across 14 countries, the largest areas of land acquired for plantation forestry are in Mozambique, particularly Niassa Province, where 6 projects have collectively gained access to 961413 ha (equivalent to $60.7 \%$ of the total area acquired in Mozambique). The

14 Of the 32 projects led by Indian investors in sub-Saharan Africa, 19 are in Ethiopia.
Malonda Foundation, ${ }^{15}$ a local nonprofit organisation promoting investments in Niassa Province, has been particularly instrumental in facilitating these investments (Åkesson et al. 2009).

\section{Reflection on impacts}

While the primary purpose of this paper is not to reflect on the impacts of large-scale farmland acquisitions, the data does give some insight into the potential risks associated with these types of investment.

Firstly, country data on the scale of farmland acquisitions provides a perspective on the potential competition with other important land uses. This can be illustrated by contrasting the total area acquired with the extent of available and suitable land. As can be discerned from Table 4, the threat of farmland acquisitions competing with other land uses (in this case existing agricultural and forested land) varies greatly between countries. In Ethiopia the magnitude of documented acquisitions is equivalent to up to $42.9 \%$ of the total area considered potentially available and suitable for agriculture; in Ghana it is $61.6 \%$. In other words, the risk is comparatively high in these countries that farmland acquisitions are displacing other important land uses and land users, with potential implications for long-term food security, the environment, and rural livelihoods. In Ghana, farmland acquisitions take place particularly at the expense of small-scale subsistence agriculture; while in Ethiopia it is particularly land with low population densities, but of high environmental significance, that is being transferred to investors (personal observations). In other major investment destinations, such as Madagascar and Mozambique, the proportion of the total available land acquired is significantly smaller due to the abundance of potentially available and suitable land. This though does not imply that impacts are necessarily less severe, particularly in the absence of regulations to guide land allocations.

Although the threat of land use competition would likely be less severe when existing plantations are acquired, the data suggests that the great majority of projects are 'Greenfield' developments. For only 22 projects (covering 1239983 ha: 6.8\% of the total

15 The Malonda Foundation is a private sector development program jointly funded by the Government of Sweden and the Government of Mozambique. 
Table 4. Land acquisitions and land availability

\begin{tabular}{lccc}
\hline \multirow{2}{*}{ Country } & Total area available & \multicolumn{2}{c}{ Land acquired, as \% of available land } \\
\cline { 3 - 4 } (in million ha) & & Category 1 data & All data categories \\
\hline Ghana & 3.24 & 47.1 & 61.6 \\
Ethiopia & 4.73 & 37.6 & 42.9 \\
Gabon & 0.95 & 35.1 & 35.1 \\
Nigeria & 1.31 & 26.8 & 29.0 \\
Republic of the Congo & 3.48 & 23.6 & 23.6 \\
Mali & 3.91 & 20.1 & 21.5 \\
Zambia & 13.02 & 13.5 & 14.3 \\
Madagascar & 16.24 & 9.3 & 10.8 \\
Mozambique & 16.26 & 8.8 & 9.9 \\
Tanzania & 8.66 & 5.7 & 8.7 \\
Kenya & 4.62 & 6.7 & 7.5 \\
Cameroon & 4.65 & 2.9 & 3.9 \\
Angola & 9.68 & 1.5 & 2.1 \\
Democratic Republic of the Congo & 22.50 & 1.0 & 1.3 \\
\hline
\end{tabular}

a Figures on land availability are based on total land suitable for cultivation, minus cultivated, forested and protected land, and areas with a population density of $>25$ people $/ \mathrm{km}^{2}$. For some countries (e.g. Liberia, Sierra Leone and South Sudan) data was unavailable. Availability data for Ghana does not account for population density - therefore, the presented figure overstates availability.

Source: Availability data from Fischer and Shah (2010)

area) was there evidence that parts of the acquired lands were previously used for similar purposes. Such projects typically involve abandoned estates in post-conflict countries: projects in Liberia and the DRC account for almost $84 \%$ of the total area of land acquired that was previously used for similar purposes.

Insights into potential impacts can also be gained from assessing the terms of land acquisition. None of the acquisitions entail the outright purchase of land, and, thereby the acquisition of a freehold title. In most countries in sub-Saharan Africa, the sale of land is forbidden, particularly large areas of agricultural land to foreign entities. Hence, almost all the rights to the land are obtained through a leasehold title.

Considering that approximately $77 \%$ of land in sub-Saharan Africa falls within the customary domain (Alden Wily 2011), presumably most of the leased land was previously under some sort of system of customary tenure. Country-level research has indicated this to be so in the great majority of large-scale farmland acquisitions (see, for example, Habib-Mintz 2010, Nhantumbo and Salomão 2010, Andrew and van Vlaenderen 2011, Baxter 2011a, Deng 2011, German et al. 2011, Rahmato 2011, Schoneveld et al. 2011). Much of the remaining land typically falls within the domain of the state, mostly consisting of protected areas.

The legal status of systems of customary tenure differs greatly between countries. Some countries, such as Ghana, Mozambique and Zambia explicitly recognise customary rights, while other countries, such as Ethiopia, Mauritania and Rwanda do not afford customary rights any legal protection (e.g. all land is owned by the state). Despite these differences, even in countries where customary rights are protected by law, this rarely translates into full tenure security. As a result of various governance shortcomings, customary land users are seldom consulted or requested to acquiesce to land alienations, typically with detrimental implications for livelihoods and social identity. This appears to be the near unanimous consent of country-level research into African farmland acquisitions. 
Table 5. Terms of leasehold in selected countries

\begin{tabular}{|c|c|c|}
\hline Country & Typical leasehold duration & Typical annual cost of leasehold \\
\hline Ethiopia & $25-50$ years, conditional on performance & $\begin{array}{l}\text { Fixed rates set by individual regional } \\
\text { government: as of } 2010 \text {, rent on new leases is } \\
\text { typically US } \$ 4.12-9.19 \text { per ha }^{a}\end{array}$ \\
\hline Ghana & $\begin{array}{l}50 \text { years for foreign investors; } 99 \text { years for } \\
\text { domestic investors }\end{array}$ & $\begin{array}{l}\text { Fully negotiable with traditional authorities. } \\
\text { No fixed rates. Profit sharing agreements in lieu } \\
\text { of fixed rents are common }\end{array}$ \\
\hline Liberia & $\begin{array}{l}\text { Negotiable with government. Recent leases } \\
\text { are } 20-63 \text { years, typically with performance } \\
\text { requirements }\end{array}$ & $\begin{array}{l}\text { No fixed rates, though relatively standardised } \\
\text { in practice: US } \$ 2.50-5.00 \text { per ha for 'developed } \\
\text { land'; US } \$ 1.25 \text { per ha for 'undeveloped land' }\end{array}$ \\
\hline Mali & $\begin{array}{l}30 \text { years (ordinary lease) or } 50 \text { years (long-term } \\
\text { lease) }\end{array}$ & $\begin{array}{l}\text { No fixed rates. Leaseholds for commercial } \\
\text { agriculture are typically free of charge }\end{array}$ \\
\hline Mozambique & $\begin{array}{l}\text { 2-5 year conditional performance-based lease, } \\
\text { then } 50 \text { year lease }\end{array}$ & $\begin{array}{l}\text { Fixed rates set by government: US } \$ 0.60 \text { per ha } \\
\text { for agricultural land }\end{array}$ \\
\hline Sierra Leone & $\begin{array}{l}50 \text { years for foreign investors; } 99 \text { years for } \\
\text { domestic investors }\end{array}$ & $\begin{array}{l}\text { No fixed rates. Government recommends } \\
\text { US } \$ 12 \text { per ha, though in practice it is US } \$ 5-20 \\
\text { per ha }\end{array}$ \\
\hline Tanzania & $\begin{array}{l}\text { Up to } 99 \text { years; biofuel investments up to } 25 \\
\text { years }\end{array}$ & Fixed rate set by government: US $\$ 0.27$ per ha ${ }^{a}$ \\
\hline Zambia & $\begin{array}{l}99 \text { years. In practice, leaseholds are first held in } \\
\text { trust for } 2-5 \text { years to ensure performance and } \\
\text { prevent speculation }\end{array}$ & Fixed rate set by government: US $\$ 0.99$ per ha ${ }^{a}$ \\
\hline
\end{tabular}

a Converted from local currencies to US $\$$ at 20 October 2011 exchange rates.

Source: Baxter (2011a), Baxter (2011b), German et al. (2011), World Bank (2011), individual country legislation

What these reflections highlight is that (a) most of the acquired land originates from the customary domain, (b) free, prior and informed consent of land users is rarely sought, and (c) this often results in involuntary expropriation of vital livelihood resources. In most countries, leaseholds are allocated for periods of 25-99 years, often with options to renew (see Table 5). In some countries, such as Tanzania and Zambia, all customary rights to land are indefinitely extinguished once a leasehold title is allocated, implying that the land can never revert back to its previous status (German et al. 2011). Even when it can, the duration of a typical title often spans generations. Moreover, in the advent that projects fail, titles are normally reallocated for other commercial purposes, as can be observed in the case of defunct jatropha projects in Mozambique and Tanzania. Thus, even in countries that place strict performance conditions on investors, Ethiopia and Liberia being notable examples, once land is alienated, it is often permanently removed from the customary domain. This, consequently, leads to increasing long-term concentration of land resources with commercial and state actors.
Considering the meagre rental rates in most subSaharan countries (ranging from nil to US $\$ 20$ per ha), which are typically appropriated by the state, the direct, long-term, economic returns from alienation are very limited (both at a local or national level) ${ }^{16}$.

The anticipated growth in global biofuel consumption has been a major conduit for farmland investments. With most biofuel investors primarily targeting export markets, it is unlikely that biofuel projects will make significant contributions to host country energy security. This trend will be further reinforced since few host countries have imposed domestic blending mandates (and have no capacity to put in place incentives to enable this), and as a result of global price differentials created by market distortions in mandated markets (Jumbe et al. 2009, Schoneveld et al. 2010). Biofuel projects also

16 That is not to say that there are no benefits. Local benefits can accrue in the form of compensation, direct and indirect employment, contributions to social infrastructure, and improved access to markets, amongst others. It is beyond the scope of this report to assess how effectively and equitably these benefits are captured in the different countries. 
threaten to undermine food security (particularly local) when subsistence farming is displaced for biofuel feedstocks.

While more substantial societal benefits could arguably be derived from farmland acquisitions for food projects, particularly in food insecure countries, such benefits are unlikely to materialise if the produce is exported. Since many projects are led by investors from countries that are food insecure themselves, an imperative to export is likely. A notable exception is likely to be palm oil and sugar, since few African countries are completely selfsufficient in these products and domestic prices often exceed international market prices. However, whether these products are domestic priorities, in terms of nutritional value, is questionable. In this regard, it is disconcerting to observe the comparative scarcity of projects that cultivate staple crops (e.g. cereals, pulses, starches). In sum, due to market composition (few domestic investors), market orientation (oriented towards export markets), and type of product (dominance of biofuels) these farmland investments are unlikely to make significant contributions to domestic market needs.

\section{Conclusions}

This research has helped highlight some of the key trends associated with large-scale farmland acquisition in sub-Saharan Africa. It has shown the distribution of farmland acquisitions to be widespread across sub-Saharan Africa, albeit with comparatively high concentrations in certain countries. Since 2005, the largest areas of land were found to have been acquired in Ethiopia, Ghana, Liberia, Madagascar, Mozambique, South Sudan and Zambia, collectively accounting for almost twothirds of the total area acquired. With comparatively limited areas of land that can be considered suitable and available, the magnitude of farmland acquisitions may have particularly dire social and environmental implications in Ethiopia and Ghana.

Findings suggest that these farmland acquisitions are primarily initiated by private, foreign companies, with a comparatively minor role played by domestic investors. In relation to investor origin, a similarly high geographic concentration can be observed, with companies from India, Norway, the UK and the US responsible for acquiring the largest areas of land. From a regional perspective, projects led by EU-based companies account for just under half the total area acquired by foreign projects, followed by companies originating from Asia.
One of the most significant drivers of large-scale farmland acquisitions in sub-Saharan Africa is the perceived long-term demand for biofuels in large mandate-driven markets, particularly the EU. Biofuel-related projects are responsible for almost two-thirds of the total area acquired across subSaharan Africa. However, with investor interest in the biofuel sector showing signs of abating during 2009-2011, a rise in food-related projects can be observed. Although northern investors, particularly those from the US, are responsible for a number of these projects, they originate principally from the south, notably from Asia and the Arab world. These projects stem predominantly from countries that are confronted by growing domestic barriers to expansion and, in certain cases, rapidly rising exposure to food price shocks and food insecurity.

Though it is of interest to note these distinctive geographic patterns in capital flows for the different sectors, the underlying factors driving farmland investments into sub-Saharan Africa are essentially the same: growing domestic resource scarcity in the face of rising consumption, and declining selfsufficiency for agricultural products. In the context of an ongoing quest for alternative sources of energy, growing populations, changing patterns of consumption, and climate change, this recent spatial reconfiguration of agricultural production systems is by no means transient.

While this potentially places many sub-Saharan African countries in an economically advantageous position, it is questionable whether these global market opportunities have been effectively exploited by host country governments. If anything, ineffective domestic governance of land acquisitions means the resources these countries could exploit to the benefit of their own populations are at risk of becoming isolated enclaves of foreign capital accumulation. Such processes tend to take place at the expense of socially and environmentally valuable land uses and on terms that do not reflect the land's true economic potential. As sub-Saharan Africa increasingly internalises the costs of global resource scarcity while its gains are exported, it once again gives reason to consider the distributional effects of globalisation and the relevance of market governance.

Given the geopolitical nature of the phenomenon, greater accountability should not only be expected of host country governments, but also of the market and consumer countries themselves. This could be realised through initiatives to legislate sustainability requirements in consumer markets, the development 
of more stringent due diligence standards by financial institutions, greater transparency by private equity and venture capital funds, dedicated voluntary certification systems, and multilateral and bilateral technical support to the development of host country governance systems - guided by some of the 'best practice principles' currently under development.

\section{References}

AFP 2011 Germany blames Chinese land buys for Africa drought. Agence FrancePresse, 28 July. http://www.google.com/ hostednews/afp/article/ALeqM5hu9_tN9w_ dCvyWeYhfdOJLCn47BA?docId=CNG. f7f7219253feb49f37e24ef89a4ad717.4d1 (8 September 2011).

Åkesson, G., Calengo, A. and Tanner, C. 2009 Study on community land rights in Niassa Province, Mozambique. Rapporter Institutionen för stad och land 6. Swedish International Development Cooperation Agency (SIDA), Stockholm, Sweden.

Alden Wily, L. 2011 The law is to blame: the vulnerable status of common property rights in sub-Saharan Africa. Development and Change 42(3): 733-757.

Andrew, M. and van Vlaenderen, H. 2011 Commercial biofuel land deals and environment and social impact assessments in Africa: three case studies in Mozambique and Sierra Leone. Working Paper 1. Land Deal Politics Initiative, Cape Town, South Africa.

Anseeuw, W. and Taylor, M. 2011 Commercial pressures on land. Presentation, International Conference on Global Land Grabbing, Sussex, 6 April. http://www.future-agricultures.org/ index.php?option $=$ com_docman $\&$ task $=$ doc_ download $\&$ gid $=1307 \&$ Itemid $=971$ (3 September 2011).

Associated Press 2008 China farms the world to feed a ravenous economy. 4 May. http:// farmlandgrab.org/2339 (15 August 2011).

Atanasiu, S. 2010 The role of bioenergy in the national renewable energy action plans: a first identification of issues and uncertainties. Institute for European Environmental Policy, London.

Baxter, J. 2011a Understanding land investment deals in Africa - Country Report: Sierra Leone. The Oakland Institute, Oakland, USA.
Baxter, J. 2011b Understanding land investment deals in Africa - Country Report: Mali. The Oakland Institute, Oakland, USA.

Braun, J. von and Meinzen-Dick, R. 2009 'Land grabbing' by foreign investors in developing countries: risks and opportunities. Policy Brief. International Food Policy Research Institute, Washington, D.C.

Carter, E., Adams, W.M. and Hutton, J. 2008 Private protected areas: management regimes, tenure arrangements and protected area categorisation in East Africa. Oryx 42: 177-186.

CFTC 2011 The month in futures markets: the complete history. Commodity Futures Trading Commission. http://www.cftc.gov/OCE/WEB/ index.htm (19 September 2011).

Clark, C.J., Poulsen, J.R., Malonga, R. and Elkan, P.W. 2009 Logging concessions can extend the conservation estate for central African tropical forests. Conservation Biology 23: 1281-1293.

Cotula, L., Vermeulen, S., Leonard, R. and Keeley, J. 2009 Land grab or development opportunity? Agricultural investment and international land deals in Africa. International Institute for Environment and Development, Food and Agriculture Organization, and International Fund for Agricultural Development, London and Rome.

Daily Motion 2010 Atama plantation entend investir dans l'agro-industrie. 18 December. http:// www.dailymotion.com/video/xg6dy0_atamaplantation-entend-investir-dans-l-agro-industrie_ news (8 January 2011).

de Schutter, O. 2011 How not to think of landgrabbing: three critiques of large-scale investments in farmland. Journal of Peasant Studies 38: 249-279.

Deininger, K. 2011 Challenges posed by the new wave of farmland investment. Journal of Peasant Studies 38: 217-247.

Deng, D.K. 2011 Land belongs to the community: Demystifying the 'global land grab' in Southern Sudan. Working Paper 4. Land Deal Politics Initiative, Cape Town, South Africa.

Economist 2011 When others are grabbing their land: evidence is piling up against acquisitions of farmland in poor countries. 5 May. http:// www.economist.com/node/ 18648855 (15 August 2011).

EIA 2011 International Energy Statistics. US Energy Information Administration. http:// 
www.eia.gov/cfapps/ipdbproject/IEDIndex3. cfm?tid=79\&pid=79\&aid=1 (19 August 2011).

FAO 2011 FAO Food Price Index. http://www. fao.org/worldfoodsituation/wfs-home/ foodpricesindex/en/ (2 November 2011) Financial Times 2011. Sime Darby eyes oil palm expansion in Africa. 27 February. http://www. ft.com/cms/s/0/290c6a52-42ad-11e0-8b3400144feabdc0.html\#axzz1bNVbytOK (28 March 2011).

Fischer, G., Hizsnyik, E., Shah, M. and Velthuizen, H. 2009 Biofuels and food security: implications of an accelerated biofuels production. Summary of the OFID prepared by the International Institute for Applied Systems Analysis. OFID Pamphlet Series. The OPEC Fund for International Development, Vienna, Austria.

Fischer, G. and Shah M. 2010 Farmland Investments and Food Security: Statistical Annex. Report prepared under World Bank and International Institute for Applied System Analysis contract, Luxembourg.

GEM Biofuels 2010 Annual Report 2009. GEM Biofuels, London.

German, L.A., Schoneveld, G.C. and Mwangi, E. 2011 Contemporary processes of land acquisitions by investors: Case studies from subSaharan Africa. Occasional Paper 68. CIFOR, Bogor, Indonesia.

Government of the DRC 2007 Convention de Partnenariat entre le RD Congo et la ZTE International Investments Co. Ltd. en vue de l'implantation et de l'exploitation d'une palmaraie industrielle. Ministry of Agriculture, Kinshasa, Democratic Republic of the Congo.

Government of Ethiopia 2010 Land rental contract agreement between the Ministry of Agriculture and Rural Development and Karuturi Agro Products plc. Ministry of Agriculture and Rural Development, Addis Ababa, Ethiopia.

Government of Ghana 2008 Environmental impact statement for ScanFuel. Environmental Protection Agency, Accra, Ghana.

Government of Liberia 2009 Concession agreement between the Republic of Liberia and Sime Darby Plantations. Ministry of Agriculture, Monrovia, Liberia.

Government of South Sudan 2008 Lease agreement between Makaya Payam Cooperative and Nile Trading and Development. Ministry of Agriculture, Juba, South Sudan.
Government of Zambia 2005 Farm Block Development Plan. Ministry of Agriculture and Cooperatives, Lusaka, Zambia.

Government of Zambia 2009 Second report of the committee on agriculture and lands for the fourth session of the tenth national assembly appointed on Thursday, 24th September, 2009. Parliament, Lusaka, Zambia.

Government of Zambia 2010a Mining concessions in Zambia. Dataset. Ministry of Mines, Lusaka, Zambia.

Government of Zambia 2010b Environmental project brief for Ferrostaal Jatropha Project. Environmental Council of Zambia, Lusaka, Zambia.

GRAIN 2009 Corporate investors lead the rush for control over overseas farmland. GRAIN, Barcelona, Spain.

Habib-Mintz, N. 2010 Biofuel investment in Tanzania: omissions in implementation. Energy Policy 38: 3985-3997.

Hall, R. 2011 Land grabbing in southern Africa: the many faces of the investor rush. Review of African Political Economy 38: 193-214.

IMF 2011 Primary Commodity Prices. http://www. imf.org/external/data.htm (2 November 2011)

IOI Group 2010 Newsletter July-September. http://www.ioigroup.com/newsroom/ beritaIOIpdfversion/Issue47.pdf (8 January 2011).

Jumbe, C.B.L., Msiska, F.B.M. and Madjera, M. 2009 Biofuels development in sub-Saharan Africa: are the policies conducive? Energy Policy 37: 4980-4986.

Karsenty, A. 2007 Overview of industrial forest concessions and concession-based industry in central and west Africa and considerations of alternatives. Rights and Resources Initiative, Washington, D.C.

Karsenty, A. 2011 Large-scale acquisition of rights on forest lands in Africa. Rights and Resources Initiative, Washington, D.C.

Karuturi Global 2011 Corporate website. http:// www.karuturi.com (2 September 2011).

Kinyeti 2011 Corporate website. http://www.kinyeti. com (3 September 2011).

Knoepfel 2011 Responsible investment in commodities: the issues at stake and a potential role for institutional investors. onValues, Zurich, Switzerland. 
Merian Research/CRBM 2010 The vultures of land grabbing. Regulate Finance for Development, London.

New Scientist 2011 African land grab could lead to future water conflicts http://www.newscientist. com/article/mg21028144.100-african-land-grabcould-lead-to-future-water-conflicts.html (25 September 2011).

Newsclick 2011 African land grab: new century, new colonizers. 12 September. http://www.newsclick. in/international/africa-land-grab-new-centurymore-colonisers (14 October 2011).

NFL 2008 Natural Fuel completed jatropha offtake agreement. 14 February. http://www. finanznachrichten.de/pdf/20080214_082452_ NULL_9776B37D2221E5CB482573EF0001F 7AF.1.pdf (23 February 2009).

Nhantumbo, I. and Salomão, A. 2010 Biofuels, land access and rural livelihoods in Mozambique. International Institute for Environment and Development and Centro Terra Viva, London and Maputo, Mozambique.

Olam 2010 Investment in Greenfield oil palm plantation in Gabon. Analyst and Media Briefing, Singapore, 13 November. http:// www.olamonline.com/attachments/newsroom/ gabon_palm_ap_vnov_12_-_final_\%28short_ version\%29.pdf (3 March 2011).

Poulton, C., Tyler, G., Hazell, P., Dorward, A., Kydd, J. and Stockbridge, M. 2008 Commercial agriculture in Africa: lessons from success and failure. World Bank, Washington, D.C.

Rahmato 2011 Land to investors: large-scale land transfers in Ethiopia. Forum for Social Studies, Addis Ababa, Ethiopia.

Reuters 2008a South Korea's Daewoo to grow corn in Madagascar. 18 November. http://farmlandgrab. org/2559 (15 September 2011).

Reuters 2008b ScanFuel to start biofuel operations in Ghana. 21 November. http://in.reuters. com/article/2008/11/21/biofuels-ghanaidINLK55111220081121 (17 May 2009).

Reuters 2009a S Africa offered farmland in Congo. 15 April. http://af.reuters.com/article/ congoNews/idAFLF43982020090415 (15 September 2011).

Reuters 2009b China asks to plant $2 \mathrm{mln}$ ha of jatropha. 31 March. http://af.reuters.com/article/ zambiaNews/idAFLV96195120090331 (15 September 2011).
Reuters 2011a Mozambique offers Brazilian farmers land to plant. 15 August. http:// af.reuters.com/article/commoditiesNews/ idAFN1E77E05H20110815

(15 September 2011).

Reuters 2011b African land grab threatens food security: study. 26 July. http://www.reuters. com/article/2011/07/26/us-investment-landidUSTRE76P77P20110726 (27 July 2011).

Reuters 2011c Siva Group in Cameroon \$1.9 bln palm oil deal. 24 August. http:// af.reuters.com/article/investingNews/ idAFJOE77N01320110824

(15 September 2011).

Rowden, R. 2011 India's role in the new global farmland grab. GRAIN, Barcelona, Spain.

RSPO 2011 RSPO notification of proposed new planting. 11 February. http://www.rspo.org/ sites/default/files/8\%202\%20V2\%20Olam $\% 20$ RSPO $\% 20$ Notification $\% 20$ of $\% 20$ Proposed $\% 20$ New\%20Planting\%20Feb\%202011_0.pdf (3 March 2011).

Schoneveld, G.C. 2010 Potential land-use competition from first generation biofuel expansion in developing countries. Occasional Paper 58. CIFOR, Bogor, Indonesia.

Schoneveld, G.C., German, L.A., Andrade, R., Chin, M., Caroko, W. and Romero-Hernández, O. 2010 The role of national governance systems in biofuel development: a comparative analysis of lessons learned. Info Brief 35. CIFOR, Bogor, Indonesia.

Schoneveld, G.C., German, L.A., and Nutakor, E. 2011 Land-based investments for rural development? A grounded analysis of the local impacts of biofuel feedstock plantations in Ghana. Ecology and Society., 16(4):10.

Standard and Poor's 2011 S\&P 500. http://www. standardandpoors.com/indices/sp-500/en/ us/?indexId=spusa-500-usduf--p-us-1-(2 November 2011).

Ullenberg 2009 Foreign direct investment (FDI) in land in Madagascar. Division 45 - Agriculture, fisheries and food, Deutsche Gesellschaft für Internationale Zusammenarbeit (GIZ), Eschborn, Germany.

Wall Street Journal 2007 Jatropha plant gains steam in global race for biofuels. 24 August. http://online.wsj.com/ article/SB1 18788662080906716.html (15 September 2011). 
Wilmar 2007 Formation of 50:50 joint venture for investments in oil palm and rubber assets. Presentation to Analysts and Media. Singapore, 16 November. http://www.wilmar-international. com/investor/Olam_Presentation.pdf (3 March 2011).
World Bank 2011 Rising global interest in farmland: can it yield sustainable and equitable benefits? World Bank, Washington, D.C.

Zoomers, A. 2010 Globalisation and the foreignisation of space: seven processes driving the current global land grab. Journal of Peasant Studies 37(2): 429-447. 


\section{Annex 1. Indices compared}

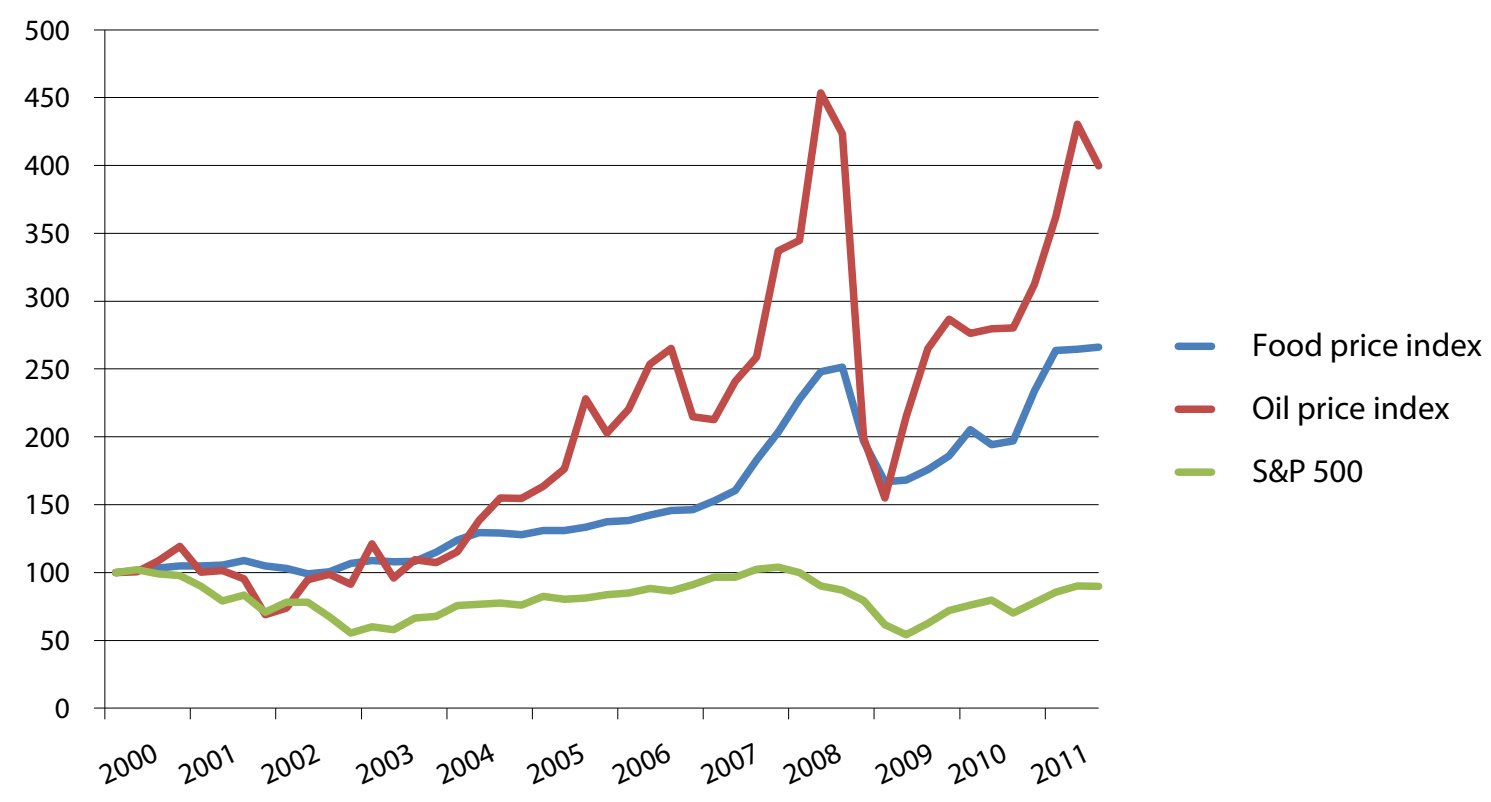

Source: Food price index from FAO (2011), Oil price index from IMF (2011), S\&P 500 index values from Standard and Poor's (2011) Note: All indices are re-indexed for the purpose of comparison (base year $=2000$ ).

\section{Annex 2. Data categories}

\section{Overview of data categories}

- Category 1: Data in this category represents data with the highest level of accuracy and is derived exclusively from the data sources detailed below. Data from these sources is only included when the land transfer agreement is legally enforceable and it is explicitly indicated that the agreement has been finalised. This category also includes conditional land lease agreements. This relates specifically to contractualised agreements that land of pre-specified extent is to be allocated once performance requirements are met. Data from other research papers is included only when data is obtained from Category 1 sources and each entry is properly referenced.

- Category 2: Data in this category represents the lowest level of data accuracy that is included in the analysis. It includes secondary data sources that do not explicitly specify data origin, such as some media reports and research publications. Data from these sources is only included when the following three conditions are met: (i) there are no conflicting reports or reasons to doubt data validity, (ii) it is expressly indicated that a land agreement has been finalised, and (iii) supplementary information on investor operations is available in the form of corporate websites, entries into company registries, or the allocation of investment licenses.

- Category 3: Data that does not fall into the above two categories is omitted from this analysis. Land agreements that are not legally enforceable (e.g. memoranda of understanding and good-faith agreements), that are in the process of being negotiated, and land areas based on projected expansion plans are, thereby, excluded. 


\section{Type of Category 1 data sources}

- leasehold or land sale contracts;

- environmental impact assessments and associated documents;

- government databases and registries, maintained by, for example, land, investment or agricultural ministries;

- official government communications (e.g. parliamentary meetings, press releases, presentations);
- official company communications (e.g. annual reports, press releases, corporate presentations);

- financial databases (e.g. official company registries, Bloomberg, Thomson Reuters);

- personal communications with key public and private sector actors;

- in-country research by CIFOR and its country partners. 


CIFOR Working Papers contain preliminary or advance research results, significant to tropical forest issues, that need to be published in a timely manner. They are produced to inform and promote discussion. Their content has been internally reviewed but not undergone the lengthier process of external peer review.

Sub-Saharan Africa has become one of the most significant targets for large-scale farmland acquisitions for plantation agriculture and forestry in recent years. While much has been written as to the opportunities and risks of this trend, scant empirical evidence is available as to its magnitude, distribution and underlying drivers. This paper addresses these knowledge gaps by analysing 353 projects that have been established since 2005 in 32 countries in sub-Saharan Africa, covering an area of about 18.1 million ha. It illustrates a high geographic concentration of investments, with two-thirds of the area acquired by large-scale farmland projects located in just seven countries and the comparatively significant role of the international biofuel and vegetable oil sectors.

The foremost driver of these farmland acquisitions was found to be the perception by 'northern' investors, particularly from Europe, of a long-term demand for alternative sources of energy in industrialised countries. Another important driver was observed to be the demand for food products in 'southern' countries, notably from Asia and the Middle East, exposed by rising domestic land constraints and/ or food insecurity. In some countries the scale of these farmland acquisitions equates to a sizeable proportion of suitable and 'available' land, by and large originating from the customary land domain. These findings, among others, highlight how a growing number of sub-Saharan countries are increasingly internalising the costs of growing external resource scarcity. This not only calls into question the distributional effects of globalisation, but also the efficacy of global market governance.

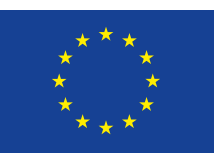
policies and practices that affect forests in developing countries. CIFOR is one of 15 centres within the Consultative Group on International Agricultural Research (CGIAR). CIFOR's headquarters are in Bogor, Indonesia. It also has offices in Asia, Africa and South America. 